\section{Stem Versus Foliar Uptake During Propagation of Petunia $\times$ hybrida Vegetative Cuttings}

\author{
Kathryn M. Santos ${ }^{1}$ and Paul R. Fisher \\ Department of Environmental Horticulture, University of Florida, Fifield \\ Hall, P.O. Box 110670, Gainesville, FL 32611
}

\author{
William R. Argo \\ Blackmore Company, 10800 Blackmore Avenue, Belleville, MI 48111
}

Additional index words. adventitious root development, aeroponics, foliar fertilization, nitrogen, phosphorus, potassium

\begin{abstract}
Nutrient uptake during adventitious root formation is not clearly understood, resulting in variable fertilization strategies in propagation and increased potential for nutrient deficiency or nutrient runoff. The objective was to quantify rooting response to fertility treatments and tissue nutrient concentration changes in response to basal or apical nutrient supply during three rooting phases in propagation of Petunia $\times$ hybrida 'Supertunia Royal Velvet' and 'Supertunia Priscilla' stem tip cuttings. One of two treatments [a complete fertilizer solution (in $\mathrm{mg} \cdot \mathrm{L}^{-1}$ ) $56 \mathrm{NO}_{3}-\mathrm{N}, 19 \mathrm{NH}_{4}-\mathrm{N}, 13$ phosphorus, 88 potassium, 39 calcium, 28 magnesium, 20 sulfur, 11 sodium, 1.1 iron, 0.5 manganese, 0.5 zinc, 0.25 copper, 0.29 boron, 0.1 molybdenum, and 0.01 aluminum] or clear tap water was applied to the cuttings. Tissue $\mathbf{N}-\mathbf{P}-\mathrm{K}$ concentrations declined as plant development increased from Stage 0 to 3 regardless of fertilizer treatment or location applied. Foliar application of $\mathbf{N}-\mathbf{P}-\mathrm{K}$ during propagation maintained tissue nutrient concentration at higher levels before Stage 2 (initial root emergence) compared with plants that received clear water only; however, overall, a decline in concentration was measured from Stage 1 to Stage 3. Measurable N-P-K uptake occurred during root development from the foliar and basal portions of the cuttings. Basal fertilizer applications resulted in increased root length and root number compared with plants treated with clear water. These results emphasize that nutrient uptake occurs from both the stem and foliar portion of Petunia cuttings, and nutrient availability at the stem base at root emergence improves root development.
\end{abstract}

A decline in tissue nutrient concentration was observed in petunia and poinsettia during the first phase of root development (Santos, 2009; Svenson and Davies, 1995). Nutrient applications during this phase have the potential to alleviate tissue nutrient decline and maintain nutrient levels within recommended ranges. Combined macronutrient and micronutrient mineral nutrient applications to petunia apical stem cuttings during the first $7 \mathrm{~d}$ of propagation maintained tissue nutrient concentrations at higher concentrations $[4.8 \%$ nitrogen $(\mathrm{N})]$ compared with cuttings that received micronutrients only $(3.7 \% \mathrm{~N})$ (Santos, 2009). Tissue nutrient decline has been attributed to dilution and foliar leaching (Blazich, 1988; Svenson and Davies, 1995; Tukey, 1967). Foliar nutrient applications before root emergence potentially serve to 1) replenish preplant nutrients leached from the substrate, which are subsequently taken up by the cut

Received for publication 7 July 2009. Accepted for publication 31 Aug. 2009.

We thank the Young Plant Research Center Partners, the American Floral Endowment, and Dramm Corporation for their financial support.

${ }^{1}$ To whom reprint requests should be addressed; e-mail pfisher@ufl.edu. stem through the transpiration stream or newly emergent roots; or 2) supply nutrients for direct foliar uptake.

Once severed from the stock plant, hormones such as ethylene, jasmonates, and auxins increase at the stem base and subsequently play diverse roles in initiating adventitious root development (Ahkami et al., 2008; Blakesley et al., 1994; Clark et al., 1999; De Klerk et al., 1999; Schilmiller and Howe, 2005; Shibuya et al., 2004; Sorin et al., 2006). Physiologically, the plant begins to respond to the severance first by callus and then by root formation, which are two independent processes (Dole and Gibson, 2006). As soon as the cutting is removed from the stock plant, the outer cells form a protective layer of necrotic cells and suberin (hydrophobic substance) (Dole and Gibson, 2006). The living cells beneath the protective layer begin to divide and form callus (Dole and Gibson, 2006). When the swollen callus area turns white or tan, the epidermis ruptures and causes the callus to crack because of root differentiation (Dole and Gibson, 2006). In petunia, callus is typically formed in 5 to $7 \mathrm{~d}$, and roots develop in 9 to $14 \mathrm{~d}$ (Dole and Gibson, 2006).

Water mist applications during the first phase of propagation (before root emer- gence) are intended to maintain plant turgidity and minimize transpiration. During a typical petunia or calibrachoa production cycle $(28 \mathrm{~d})$, the water volume applied can exceed the container capacity of the substrate, causing leaching of preplant nutrient charge (Santos et al., 2008). Transpiration was observed to increase by nearly $50 \%$ on visible root emergence in poinsettia (Wilkerson and Gates, 2005). Water moves in plants along gradients of water potential typically generated by transpirational water loss from leaves (Sheriff, 1984). Therefore, potential for nutrient uptake from the base of the stem (through the transpiration stream) should also increase at initial root emergence.

Environmental, structural, and morphological characteristics within a given plant species contribute to the efficacy of foliar nutrient applications. Physiological factors that affect the efficacy of foliar fertilization are the nutrient forms applied, the root temperature, root osmotic potential, leaf age, and current nutrient status in the tissue (Mengel, 2002; Weinbaum, 1996). Plant leaves are specialized organs primarily functioning in the production of organic compounds through photosynthesis. Foliarapplied compounds penetrate the leaf surface through the cuticle through cuticular cracks and imperfections or through stomata, leaf hairs, and other specialized epidermal cells (Burkhardt and Eichert, 2001; Tukey et al., 1961).

In contrast to roots, the outer walls of the epidermal cells in all aerial plant organs are covered with a hydrophobic cuticle (Marschner, 1995), which has the potential to limit nutrient absorption. The waterphobic cuticle is a limiting barrier for twoway transport of water and solutes in and out of the leaves (Marschner, 1995); however, neutral, noncharged molecules have been found to penetrate the cuticle by diffusion and dissolution of cuticular waxes (Schonherr, 2001). The mechanism of cuticle penetration of water and ions is not fully understood but may occur as a result of the existence of aqueous pores (Schonherr and Schreiber, 2004). In general, the micronutrient requirement can be better met by foliar application than macronutrient requirements because in absolute terms, higher quantities of macronutrients are needed (Mengel, 2002).

Given that our research has found an increase in nitrogen, phosphorus, and potassium when fertilizer was applied by root formation, our question was whether this uptake was occurring through some combination of basal and foliar uptake. Therefore, we wanted to determine if applications were recharging nutrients in the substrate or if true foliar uptake occurred. The objective of this research was to quantify rooting response to fertility treatments and tissue nutrient concentration changes in response to basal or apical nutrient supply during three rooting phases in propagation of Petunia $\times$ hybrida 'Supertunia Royal Velvet' and 'Supertunia Priscilla' cuttings. 


\section{Materials and Methods}

Aeroponics design. An aeroponics system was developed with the capability to apply isolated nutrient solutions to the foliar or basal portion of petunia vegetative cuttings simultaneously as shown in Figure 1. The bottoms of $9610.8-\mathrm{L}$ plastic tubs $(29.2 \times 34.3 \times$ $13.3 \mathrm{~cm})$ were removed and the opening was covered with a water-resistant, flexible polystyrene foam sheet attached using contact adhesive to form a waterproof seal. Fortynine equally spaced crosses $(0.8 \mathrm{~cm} \times 0.8 \mathrm{~cm})$ were made in the foam. Petunia $\times$ hybrida 'Supertunia Royal Velvet' (Expt. 1) apical stem cuttings from Innova Plant, Costa Rica, were inserted into each cross. The base of each cutting was $\approx 0.5$ to $0.8 \mathrm{~mm}$ below the foam sheet. The foliar portion of the cutting was above the foam sheet. A cross-shaped, rather than a circular, hole was used because it held the plant in place while allowing for the minor variability in stem diameter. One of two treatments [a complete fertilizer solution (in $\left.\mathrm{mg} \cdot \mathrm{L}^{-1}\right) 56 \mathrm{NO}_{3}-\mathrm{N}, 19 \mathrm{NH}_{4}-\mathrm{N}, 13$ phosphorus (P), 88 potassium $(\mathrm{K}), 39$ calcium $(\mathrm{Ca}), 28$ magnesium (Mg), 20 sulfur $(\mathrm{S}), 11$ sodium $(\mathrm{Na}), 1.1$ iron $(\mathrm{Fe}), 0.5$ manganese $(\mathrm{Mn}), 0.5$ zinc $(\mathrm{Zn}), 0.25$ copper $(\mathrm{Cu}), 0.29$ boron $(\mathrm{B})$, 0.1 molybdenum (Mo), and 0.01 aluminum (Al) or tap water $3 \mathrm{NH}_{4}-\mathrm{N}, 0.2 \mathrm{P}, 3 \mathrm{~K}, 19 \mathrm{Ca}$, $18 \mathrm{Mg}, 19 \mathrm{~S}, 11 \mathrm{Na}, 0.1 \mathrm{Fe}, 0.04 \mathrm{~B}, 0.01 \mathrm{Mo}$, and $0.01 \mathrm{Al}]$ was applied in a complete factorial arrangement to the apical or basal portion of each cutting.

The experiment was run twice: 1) $3 \mathrm{Dec}$. 2008 and 2) 30 Jan. 2009 and the design was a split plot design in a randomized complete block design with foliar fertilizer treatment as the whole plot and basal fertilizer treatment as the subplot, as shown in Figure 2. A different cultivar, Supertunia Priscilla, was used in the second experiment as a result of unavailability of 'Supertunia Royal Velvet'. The alternate cultivar, Supertunia Priscilla, was from the same supplier and had a similar growth habit to 'Supertunia Royal Velvet'. The experimental unit was a 10.8 -L plastic tub $(29.2 \times 34.3 \times 13.3 \mathrm{~cm})$ that contained 49 plants. Each experimental unit was placed above a JetRain mist nozzle $\left(1.2 \mathrm{~L} \cdot \mathrm{min}^{-1}\right)$ (Dramm, Manitowac, WI). Each whole plot contained 24 units (12 units per split plot) and there was a total of four whole plots and eight split plots for a total 96 units. Base treatments were randomized within each split plot; six applied complete fertilizer and six applied clear water and overhead treatments were randomized between whole plots. Plots were split in half by overhead mist treatment. Two overhead JetRain mist nozzles spaced 91.4 $\mathrm{cm}$ apart applied either the complete fertilizer or clear water treatment. Overhead and underneath mist intervals were set to $15 \mathrm{~min}$ for $5 \mathrm{~s}$ during the day and $35 \mathrm{~min}$ for $5 \mathrm{~s}$ at night for the duration of the experiment.

Growing environment and mist frequency were controlled by a greenhouse environmental control system (Hortimax Gemlink Environmental Control System, Rancho Santa Margarita, CA) and heating/ventilation set points were $20 / 22{ }^{\circ} \mathrm{C}$ during the day and night, providing an average of 22.1 and $21.7^{\circ} \mathrm{C}$ during the night and 24.0 and $23.9^{\circ} \mathrm{C}$ during the day in Expts. 1 and 2, respectively. The average daily light integral inside the greenhouse was 5.9 and $6.1 \mathrm{~mol} \cdot \mathrm{m}^{-2} \cdot \mathrm{d}$ in Expts. 1 and 2, respectively.

Data were analyzed using Proc Mixed in SAS (Version 9.1; SAS Institute, Cary, NC) as a split plot design with foliar fertilizer treatment as the main plot and base fertilizer treatment as the split plot. The experiments were analyzed separately because different cultivars were used in each. Dry weight and tissue nutrient concentration were measured at three developmental stages: 1) before visible root emergence; 2) at initial visible root emergence; and 3) when average root length was greater than $1 \mathrm{~cm}$ in the clear water above and clear water below treated plants. Plant tissue was washed in a $0.2 \% \mathrm{P}$ free detergent solution followed by $0.05 \mathrm{~N}$ $\mathrm{HCl}$ and deionized water before analysis as described by Jones (2001). Data were analyzed by developmental stage, which was treated as a categorical variable, and means within each developmental stage were separated by least squared means analysis. Two experimental units per block per treatment combination (above $\times$ below) were destructively sampled (eight units per combination per block) at each developmental stage. Nutrient uptake was calculated by subtracting the product of the total dry weight (in milligrams) and the tissue nutrient concentration $(\mathrm{N}, \mathrm{P}$, or $\mathrm{K})$ at Stage 1,2 , or 3 by the product of the total dry weight (in milligrams) and the tissue nutrient concentration $(\mathrm{N}, \mathrm{P}$, or $\mathrm{K})$ at Stage 0 . Root length, root number, and root dry weight were also measured on the final data collection date.

\section{Results and Discussion}

Callus formation (Stage 1) was observed 3 and $4 \mathrm{~d}$ after placing cuttings in substrate, initial root emergence (Stage 2) was observed 6 and $7 \mathrm{~d}$ after insertion, and average root lengths were greater than $1 \mathrm{~cm}$ in the clear water above and clear water below treated plants (Stage 3) 9 and $10 \mathrm{~d}$ after insertion in Expts. 1 and 2, respectively. This timing of root developmental stages was consistent with a schedule described for petunia propagation by Dole and Gibson (2006).

Nutrient concentration. Tissue N, P, and $\mathrm{K}$ concentrations declined as plant development increased from Stage 0 to 3 regardless of fertilizer treatment or location applied (Table 1). However, foliar fertilization during the early stages of root development maintained higher tissue $\mathrm{N}, \mathrm{P}$, and $\mathrm{K}$ concentrations in Petunia $\times$ hybrida 'Supertunia Priscilla' cuttings compared with cuttings that were treated with clear tap water (Table 1). Fertilizer treatments applied to the basal portion of the cuttings maintained higher tissue $\mathrm{N}$ (both experiments), $\mathrm{P}$ (Expt. 2), and $\mathrm{K}$ (Expt. 2) concentrations compared with cuttings treated with clear water (Table

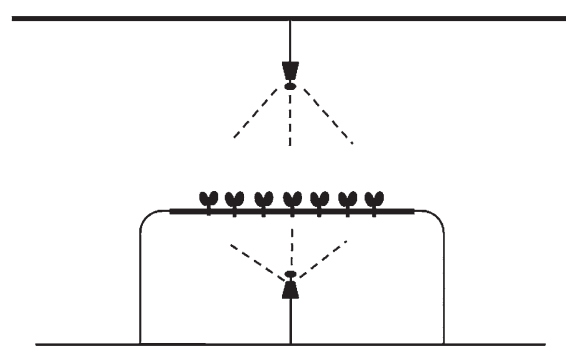

Fig. 1. Aeroponics system design. Separate nutrient solutions $\left[75 \mathrm{mg} \cdot \mathrm{L}^{-1}\right.$ of a complete fertilizer $(\mathrm{F})$ or clear tap water $(\mathrm{C})]$ were applied through mist nozzles to the foliar or basal portions of petunia unrooted cuttings placed in holes in a water-resistant flexible polystyrene foam sheet in four possible combinations: $\mathrm{F}$ above $\mathrm{F}$ below, $\mathrm{F}$ above $\mathrm{C}$ below, $\mathrm{C}$ above $\mathrm{F}$ below, or $\mathrm{C}$ above $\mathrm{C}$ below.

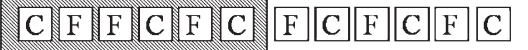

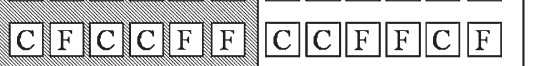

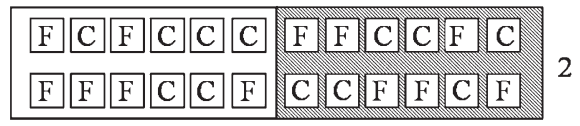

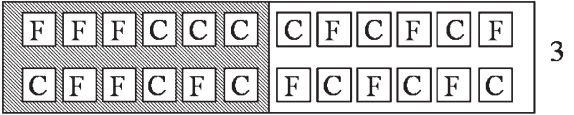

\begin{tabular}{|c|c|}
\hline 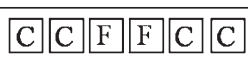 & F $F C F \quad C$ \\
\hline 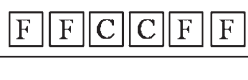 & $\begin{array}{llllll}C & C & F & C & F & F \\
\end{array}$ \\
\hline
\end{tabular}

\section{$\mathbb{N}$ Fertilizer Above \\ Clear Water Above}

Fig. 2. Aeroponics split plot design consisting of four whole plots (1 to 4$)$. Plots were split by foliar nutrient solution treatment fertilizer $(\mathrm{F}$, dashed rectangles) or clear water $(\mathrm{C}$, white rectangles). Each subplot was randomized with either fertilizer (F) or clear water (C) treatments applied to the basal portion of each cutting. Each square containing a letter represents a replicate container receiving either $\mathrm{F}$ or $\mathrm{C}$.

1). Initial $\mathrm{N}, \mathrm{P}$, and $\mathrm{K}$ tissue concentrations differed between Expts. 1 and 2.

There was an interaction between stage and foliar treatment on percent $\mathrm{N}$ in Expt. 1, percent $\mathrm{K}$ in Expt. 2, and between stage and basal treatment on percent $\mathrm{N}$ in Expts. 1 and 2 (data not shown). Fertilizer applied to the foliage resulted in increased percent $\mathrm{N}$ in Stages 2 and 3 but not in Stage 1, and percent $\mathrm{K}$ in plants that received foliar fertilizer at Stage 2 was equivalent to the percent $\mathrm{K}$ in plants that received clear water foliar applications at Stage 1. Similarly, basal fertilizer applications maintained higher tissue $\mathrm{N}$ concentrations by Stage 3 (Expt. 1) and by Stage 2 (Expt. 2) compared with clear water applications.

Foliar application of $\mathrm{N}, \mathrm{P}$, and $\mathrm{K}$ during propagation maintained tissue nutrient concentration at higher levels before Stage 2 (initial root emergence) with plants that received clear water only (Expt. 2); however, overall, a decline in concentration was 
Table 1. Tissue nitrogen (N), phosphorus (P), and potassium (K) concentration of Petunia $\times$ hybrida 'Supertunia Royal Velvet' (Expt. 1) and 'Supertunia Priscilla' (Expt. 2) cuttings during three stages of adventitious root development.

\begin{tabular}{|c|c|c|c|c|c|c|c|}
\hline \multirow{2}{*}{$\begin{array}{l}\text { Analysis of } \\
\text { variance effect }{ }^{2}\end{array}$} & \multirow[b]{2}{*}{ Level } & \multicolumn{2}{|c|}{ Tissue N (\%) } & \multicolumn{2}{|c|}{ Tissue P (\%) } & \multicolumn{2}{|c|}{ Tissue K (\%) } \\
\hline & & Expt. 1 & Expt. 2 & Expt. 1 & Expt. 2 & Expt. 1 & Expt. 2 \\
\hline$\overline{\text { Stage }^{y}}$ & 1 & $5.85 \mathrm{a}$ & $4.50 \mathrm{a}$ & $0.70 \mathrm{a}$ & $0.60 \mathrm{a}$ & $4.04 \mathrm{a}$ & $4.5 \mathrm{a}$ \\
\hline \multirow{2}{*}{ Foliar } & Clear & $4.68 \mathrm{a}$ & $3.30 \mathrm{~b}$ & $0.58 \mathrm{a}$ & $0.47 \mathrm{~b}$ & $3.29 \mathrm{a}$ & $3.3 \mathrm{~b}$ \\
\hline & Fertilizer & $5.20 \mathrm{a}$ & $4.34 \mathrm{a}$ & $0.63 \mathrm{a}$ & $0.51 \mathrm{a}$ & $3.59 \mathrm{a}$ & $4.34 \mathrm{a}$ \\
\hline Basal & Clear & $4.81 \mathrm{~b}$ & $3.69 \mathrm{~b}$ & $0.60 \mathrm{a}$ & $0.48 \mathrm{~b}$ & $3.42 \mathrm{a}$ & $3.69 \mathrm{~b}$ \\
\hline Stage & & $* * *$ & $* * *$ & $* * *$ & $* * *$ & $* * *$ & $* * *$ \\
\hline Foliar & & NS & $*$ & NS & $*$ & NS & $* *$ \\
\hline Stage*foliar & & ** & NS & NS & NS & NS & ** \\
\hline Basal & & $* * *$ & $* * *$ & NS & $* * *$ & NS & $* * *$ \\
\hline Stage*basal & & * & ** & NS & NS & NS & NS \\
\hline Foliar*basal & & NS & NS & NS & NS & NS & NS \\
\hline Stage*foliar*basal & & NS & NS & NS & NS & NS & NS \\
\hline
\end{tabular}

${ }^{\mathrm{z}}$ Stage mean was $\mathrm{n}=32$ and foliar and basal means were $\mathrm{n}=48$ each. Within a given effect (stage, foliar, or basal), least square means were compared using Tukey adjustment at $P \leq 0.05$. Experiments (denoted 'Expt. 1' and 'Expt. 2') were analyzed separately.

${ }^{y}$ Development stages were: 0 , condition at insertion; 1 , callus formation; 2 , initial root emergence; and 3, when root length in plants receiving clear water above and below averaged $\approx 1 \mathrm{~cm}$.

${ }^{\times}$Nonsignificant or significant at $P \leq 0.05,0.01$, and 0.001 were identified by Ns, *, **, and ***, respectively.

Table 2. Tissue nitrogen (N), phosphorus (P), and potassium (K) uptake of Petunia $\times$ hybrida 'Supertunia Royal Velvet' (Expt. 1) and 'Supertunia Priscilla' (Expt. 2) cuttings during three stages of adventitious root development.

\begin{tabular}{|c|c|c|c|c|c|c|c|}
\hline \multirow{2}{*}{$\begin{array}{l}\text { Analysis of } \\
\text { variance effect }\end{array}$} & \multirow[b]{2}{*}{ Level } & \multicolumn{2}{|c|}{ Uptake N (mg/cutting) } & \multicolumn{2}{|c|}{ Uptake P (mg/cutting) } & \multicolumn{2}{|c|}{ Uptake K (mg/cutting) } \\
\hline & & Expt. 1 & Expt. 2 & Expt. 1 & Expt. 2 & Expt. 1 & Expt. 2 \\
\hline \multirow[t]{4}{*}{$\overline{\text { Stage }^{y}}$} & 0 & & & & & & \\
\hline & 1 & $0.19 \mathrm{~b}$ & $0.34 \mathrm{~b}$ & $0.006 \mathrm{~b}$ & $-0.009 \mathrm{a}$ & $0.05 \mathrm{~b}$ & $0.09 \mathrm{~b}$ \\
\hline & 2 & $0.34 \mathrm{a}$ & $0.50 \mathrm{~b}$ & $0.022 \mathrm{~b}$ & $-0.010 \mathrm{a}$ & $0.01 \mathrm{~b}$ & $0.09 \mathrm{~b}$ \\
\hline & 3 & $0.36 \mathrm{a}$ & $0.89 \mathrm{a}$ & $0.062 \mathrm{a}$ & $-0.003 \mathrm{a}$ & $0.25 \mathrm{a}$ & $0.25 \mathrm{a}$ \\
\hline \multirow[t]{2}{*}{ Foliar } & Clear & $0.17 \mathrm{a}$ & $0.33 \mathrm{~b}$ & $0.021 \mathrm{a}$ & $-0.010 \mathrm{a}$ & $0.05 \mathrm{a}$ & $-0.09 \mathrm{~b}$ \\
\hline & Fertilizer & $0.43 \mathrm{a}$ & $0.83 \mathrm{a}$ & $0.040 \mathrm{a}$ & $-0.004 \mathrm{a}$ & $0.21 \mathrm{a}$ & $0.37 \mathrm{a}$ \\
\hline \multirow[t]{2}{*}{ Basal } & Clear & $0.24 \mathrm{~b}$ & $0.44 \mathrm{~b}$ & $0.027 \mathrm{a}$ & $-0.010 \mathrm{a}$ & $0.12 \mathrm{a}$ & $0.06 \mathrm{~b}$ \\
\hline & Fertilizer & $0.36 \mathrm{a}$ & $0.72 \mathrm{a}$ & $0.033 \mathrm{a}$ & $-0.002 \mathrm{a}$ & $0.14 \mathrm{a}$ & $0.22 \mathrm{a}$ \\
\hline \multicolumn{8}{|l|}{ Significance $^{x}$} \\
\hline Stage & & * & $* * *$ & $* * *$ & NS & ** & * \\
\hline Foliar & & NS & $*$ & NS & NS & NS & $*$ \\
\hline Stage*foliar & & $* *$ & * & NS & NS & NS & ** \\
\hline Basal & & * & ** & NS & NS & NS & ** \\
\hline Stage*basal & & NS & NS & NS & NS & NS & NS \\
\hline Foliar*basal & & NS & NS & NS & NS & NS & NS \\
\hline Stage*foliar*basal & & NS & NS & NS & NS & NS & NS \\
\hline
\end{tabular}

${ }^{\mathrm{z} W i t h i n ~ a ~ g i v e n ~ e f f e c t ~(s t a g e, ~ f o l i a r, ~ o r ~ b a s a l), ~ l e a s t ~ s q u a r e ~ m e a n s ~ w e r e ~ c o m p a r e d ~ u s i n g ~ T u k e y ~ a d j u s t m e n t ~}$ at $P \leq 0.05$ with $\mathrm{n}=16$. Experiments (denoted 'Expt. 1' and 'Expt. 2') were analyzed separately.

${ }^{\mathrm{y}}$ Development stages were: 0 , condition at insertion; 1 , callus formation; 2 , initial root emergence; and 3 , when root length in plants receiving clear water above and below averaged $\approx 1 \mathrm{~cm}$.

${ }^{\mathrm{x}}$ Nonsignificant or significant at $P \leq 0.05,0.01$, and 0.001 were identified by $\mathrm{Ns}, *, * *$, and $* * *$, respectively.

measured from Stage 1 to Stage 3. Tissue nutrient concentration decline before root formation was also observed in poinsettia cuttings that were grown without mist; therefore, nutrient loss was not attributed to foliar leaching, but instead to dilution (Svenson and Davies, 1995). Therefore, foliar fertilization with a complete fertilizer during propagation has the potential to maintain tissue nutrient levels and thereby reduce the likelihood of falling below recommended ranges.

Measurable N, P, and K uptake occurred during root development from the foliar and basal portions of the cuttings, except for $\mathrm{P}$ uptake in Expt. 2 (Table 2). There was an interaction between stage and foliar effects on $\mathrm{N}$ uptake in both experiments $(P<0.05,0.05)$ and $\mathrm{K}$ uptake in Expt. $2(P<0.05)$ (data not shown). Nitrogen uptake increased in cuttings when fertilizer was applied to the foliage during Stages 2 and 3 but not Stage 1, and no additional $\mathrm{N}$ uptake occurred in cuttings treated with foliar clear water at Stages 1, 2, and 3. Potassium uptake occurred in cuttings when foliar fertilizer was applied compared with clear water treatments at Stages 1, 2, and 3 ; no $\mathrm{K}$ additional uptake occurred in plants treated with clear water at Stages 1, 2, and 3. The lack of additional $\mathrm{N}$ and $\mathrm{P}$ uptake in the clear water treatments is a result of the minimal amounts of those elements in the clear water treatment. In Expt 1., $\mathrm{P}$ and $\mathrm{K}$ uptake occurred by Stage 3 and K uptake was higher in plants treated with foliar fertilizer (Table 2). Nitrogen uptake was also higher in cuttings that were treated with fertilizer from the bottom (basal portion) compared with clear water in both experiments (Table 2). A net loss of $\mathrm{P}$ was measured in Expt. 2 and could be attributed to a combination of foliar leaching.
Dry weight and root growth. Initial dry weight (Stage 0) differed between the two experiments $(P<0.05)$ (Table 3$)$. Shoot dry weight increased across developmental stages (Table 3). Foliar fertilizer applications did not affect shoot dry weight; however, root dry weight was higher in plants that received fertilizer from below in both experiments (Table 3).

Basal fertilizer applications resulted in $17 \%$ increased root length from $1.15 \mathrm{~cm}$ to $7.35 \mathrm{~cm}$ compared with plants treated with clear water in Expt. 1 and $18 \%$ from $0.49 \mathrm{~cm}$ to $2.79 \mathrm{~cm}$ in Expt. 2 (Table 4). Root number also increased with basal fertilizer treatments (Table 4). Increase in root length and root number when complete fertilizer was applied directly to the root zone supports research reported by Marschner (1995) on localized nutrient supply. Nitrogen and P were shown to be the most effective nutrients in eliciting enhanced root growth (Marschner, 1995). More specifically, in annual plant species, rooting density rapidly increased in zones of higher nutrient concentrations, especially N (Marschner, 1995). Increased rooting with localized nutrient supply to the root zone observed in this study also emphasized the importance of the nutrient availability in the substrate at root emergence through the use of best management practices. Propagators that leached high volumes of water during propagation, a resourceinefficient strategy, were shown to leach most, if not all, of their preplant charge before root emergence (Santos et al., 2008).

\section{Conclusion}

The results show that localized nutrient applications to either the foliage or the cut stem of petunia cuttings resulted in increased growth, uptake, and nutrient concentration. More specifically, foliar applications tended to increase total growth and tissue nutrient concentration, and basal applications increased root growth (dry weight, length, and 
Table 3. Shoot, root, and total dry weight of Petunia $\times$ hybrida 'Supertunia Royal Velvet' (Expt. 1) and 'Supertunia Priscilla' (Expt. 2) cuttings during three stages of adventitious root development.

\begin{tabular}{|c|c|c|c|c|c|c|c|}
\hline \multirow{2}{*}{$\begin{array}{l}\text { Analysis of } \\
\text { variance effect }{ }^{y}\end{array}$} & \multirow[b]{2}{*}{ Level } & \multicolumn{2}{|c|}{ Shoot dry wt (mg) } & \multicolumn{2}{|c|}{ Root dry wt (mg) ${ }^{z}$} & \multicolumn{2}{|c|}{ Total dry wt (mg) } \\
\hline & & Expt. 1 & Expt. 2 & Expt. 1 & Expt. 2 & Expt. 1 & Expt. 2 \\
\hline \multirow[t]{4}{*}{ Stage } & $0^{\mathrm{x}}$ & $21.78 \pm 0.8$ & $24.80 \pm 0.8$ & - & - & - & - \\
\hline & 1 & $27.98 \mathrm{c}$ & $29.94 \mathrm{c}$ & - & - & - & - \\
\hline & 2 & $37.61 \mathrm{~b}$ & $36.53 \mathrm{~b}$ & - & - & - & - \\
\hline & 3 & $41.80 \mathrm{a}$ & $46.58 \mathrm{a}$ & $0.85 \pm 0.4$ & $2.32 \pm 0.3$ & $42.67 \pm 0.8$ & $48.83 \pm 2$ \\
\hline \multirow[t]{2}{*}{ Foliar } & Clear & $34.99 \mathrm{a}$ & $37.32 \mathrm{a}$ & $0.96 \mathrm{a}$ & $2.60 \mathrm{a}$ & $41.37 \mathrm{a}$ & $47.29 \mathrm{a}$ \\
\hline & Fertilizer & $36.60 \mathrm{a}$ & $38.04 \mathrm{a}$ & $0.75 \mathrm{a}$ & $2.03 \mathrm{a}$ & $43.97 \mathrm{a}$ & $50.37 \mathrm{a}$ \\
\hline \multirow[t]{2}{*}{ Basal } & Clear & $35.79 \mathrm{a}$ & $37.09 \mathrm{a}$ & $0.14 \mathrm{~b}$ & $1.35 \mathrm{~b}$ & $43.09 \mathrm{a}$ & $47.85 \mathrm{a}$ \\
\hline & Fertilizer & $35.80 \mathrm{a}$ & $38.27 \mathrm{a}$ & $1.57 \mathrm{a}$ & $3.28 \mathrm{a}$ & $42.25 \mathrm{a}$ & $49.81 \mathrm{a}$ \\
\hline \multicolumn{8}{|l|}{ Significance $^{w}$} \\
\hline Stage & & $* * *$ & $* * *$ & & & & \\
\hline Foliar & & NS & NS & NS & NS & NS & NS \\
\hline Stage*foliar & & NS & NS & & & & \\
\hline Basal & & NS & NS & $*$ & $* * *$ & NS & NS \\
\hline Stage*basal & & $*$ & NS & & & & \\
\hline Foliar*basal & & NS & NS & NS & $*$ & NS & NS \\
\hline Stage*foliar*basal & & NS & NS & & & & \\
\hline
\end{tabular}

${ }^{\mathrm{z}}$ Root dry weight was measured separate from shoot dry weight Stage 3.

${ }^{y}$ Stage mean was $n=32$ and foliar and basal means were $n=48$ and $n=16$ for root and total dry weight, respectively. Within a given effect (stage, foliar, or basal), least square means were compared using Tukey adjustment at $P \leq 0.05$. Experiments (denoted 'Expt. 1' and 'Expt. 2') were analyzed separately.

${ }^{\mathrm{x}}$ Stage 0 values were not included in the analysis of variance because treatments occurred after Stage 0 data were collected. Mean \pm SE presented for Stage 0 .

wonsignificant or significant at $P \leq 0.05,0.01$, and 0.001 were identified by Ns, *,**, and ***, respectively.

Table 4. Root length and root number of of Petunia $\times$ hybrida 'Supertunia Royal Velvet' (Expt. 1) and 'Supertunia Priscilla' (Expt. 2) during Stage 3.

\begin{tabular}{|c|c|c|c|c|c|}
\hline \multirow{2}{*}{$\begin{array}{l}\text { Analysis of } \\
\text { variance effect }\end{array}$} & \multirow[b]{2}{*}{ Level } & \multicolumn{2}{|c|}{ Root length $(\mathrm{cm})$} & \multicolumn{2}{|c|}{ Root number } \\
\hline & & Expt. 1 & Expt. 2 & $\overline{\text { Expt. } 1}$ & Expt. 2 \\
\hline \multirow[t]{2}{*}{ Foliar } & Clear & $4.63 \mathrm{a}$ & $1.68 \mathrm{a}$ & $9.88 \mathrm{a}$ & $19.06 \mathrm{a}$ \\
\hline & Fertilizer & $3.88 \mathrm{a}$ & $1.60 \mathrm{a}$ & $9.31 \mathrm{a}$ & $18.30 \mathrm{a}$ \\
\hline \multirow[t]{2}{*}{ Basal } & Clear & $1.15 \mathrm{~b}$ & $0.49 \mathrm{~b}$ & $5.76 \mathrm{~b}$ & $17.69 \mathrm{~b}$ \\
\hline & Fertilizer & $7.35 \mathrm{a}$ & $2.79 \mathrm{a}$ & $13.43 \mathrm{a}$ & $19.68 \mathrm{a}$ \\
\hline \multicolumn{6}{|l|}{ Significance $^{y}$} \\
\hline Foliar & & NS & NS & NS & NS \\
\hline Basal & & $* * *$ & $* * *$ & $* * *$ & $* *$ \\
\hline Foliar*basal & & NS & NS & NS & NS \\
\hline
\end{tabular}

${ }^{\mathrm{z}}$ Within a given effect (stage, foliar, or basal), least square means were compared using Tukey adjustment at $P \leq 0.05$ with $\mathrm{n}=16$. Experiments (denoted 'Expt. 1' and 'Expt. 2') were analyzed separately.

${ }^{y}$ Nonsignificant or significant at $P \leq 0.05,0.01$, and 0.001 were identified by Ns, *,**, and ***, respectively.

number). Foliar absorption and increased growth during and after propagation was also observed in Chrysanthemum cuttings (Tukey and Marczynski, 1984). Localized nutrient supply to the root zone increased root growth and length in accordance with research on root response to basal nutrient supply reported by Marschner (1995). In previous research, preplant charge can be very easily leached from the substrate, emphasizing the importance of proper water management strategies to ensure nutrient availability at root emergence (Santos et al., 2008). Best management strategies to minimize water use during propagation could include reducing the irrigation frequency during early propagation stages or replacing old mist nozzles with nozzles that supply smaller volumes of water (Santos et al., 2008).

Foliar nutrient applications during propagation serve a similar role as those ascribed in agricultural practices under conditions when nutrient availability is low, topsoil is dry, or root activity is reduced during reproductive stages (for a review, see Wojcik, 2004). During propagation, foliar fertilization supplemented uptake before significant root development and maintained higher tissue nutrient concentra- tions compared with cuttings that did not receive foliar nutrient supply. Differences were measured between the two experiments and these differences are attributed to both time and cultivar effects. These results are specific to petunia and therefore foliar applications to other plant species should be trialed on a small group of plants before implementing foliar fertilization practices to an entire crop.

\section{Literature Cited}

Ahkami, A.H., S. Lischewski, K.T. Haensch, S. Porfirova, J. Hofmann, H. Rolletschek, M. Melzer, P. Franken, B. Hause, U. Druege, and M.R. Hajirezaei. 2008. Molecular physiology of adventitious root formation in Petunia hybrida cuttings: involvement of wound response and primary metabolism. New Phytol. 181:613-625.

Blakesley, D. 1994. Auxin metabolism and adventitious root initiation, p. 143-153. In: Davis, T.D. and B.E. Haissig (eds.). Biology of adventitious root formation. Plenum Press, New York, NY.

Blazich, F.A. 1988. Mineral nutrition and adventitious rooting, p. 61-69. In: Davis, T.D., B.E. Hassig, and N. Sankhla (eds.). Adventitious root formation in cuttings. Dioscorides Press, Portland, OR.

Burkhardt, J. and T. Eichert. 2001. Stomatal uptake as an important factor in foliar nutrition, $\mathrm{p}$.
1046-1047. In: Horst, W.J. and H. Marschner (eds.). Plant nutrition. Kluwer Academic Publishers, Boston, MA.

Clark, D.G., E.K. Gubrium, J.E. Barrett, T.A. Nell, and H.J. Klee. 1999. Root formation in ethyleneinsensitive plants. Plant Physiol. 121:53-60.

De Klerk, G.J., W. van der Krieken, and J.C. De Jon. 1999. The formation of adventitious roots: New concepts, new possibilities. In Vitro Cell. Dev. Biol. Plant 35:189-199.

Dole, J.M. and J.L. Gibson. 2006. Cutting propagation. A guide to propagating and producing floriculture crops. Ball Publishing, Batavia, IL.

Jones, B.J., Jr. 2001. Laboratory guide for conducting soil tests and plant analysis. CRC Press, Boca Raton, FL.

Marschner, H. 1995. Mineral nutrition of higher plants. 2nd Ed. Academic Press, New York, NY.

Mengel, K. 2002. Alternative or complementary role of foliar supply in mineral nutrition. Acta Hort. 594:33-48.

Santos, K.M., P.R. Fisher, and W.R. Argo. 2008. A survey of water and fertilizer management during cutting propagation. HortTechnology 18:597-604.

Santos, K.M. 2009. Nutrient supply and uptake during propagation of Petunia cuttings. $\mathrm{PhD}$ dissertation, University of Florida, Gainesville, FL.

Schilmiller, A.L. and G.A. Howe. 2005. Systemic signaling in wound response. Curr. Opin. Plant Biol. 8:369-377.

Schonherr, J. 2001. Cuticular penetration of calcium salts: Effects of humidity, anions and adjuvants. J. Plant Nutr. Soil Sci. 164:224-231.

Schonherr, J. and L. Schreiber. 2004. Size selectivity of aqueous pores in astomatous cuticular membranes isolated from Populus canescens (Aiton) Sm. leaves. Planta 219:405-411.

Sheriff, D.W. 1984. Epidermal transpiration and stomatal responses to humidity: Some hypotheses explored. Plant Cell Environ. 7:669-677.

Shibuya, K., K.G. Barry, J.A. Ciardi, H.M. Loucas, B.A. Underwood, S. Nourizadeh, J.R. Ecker, H.J. Klee, and D.G. Clark. 2004. The central role of PhEIN2 in ethylene responses throughout plant development in Petunia. Plant Physiol. 136:349-364.

Sorin, C., L. Negroni, T. Balliau, H. Corti, M.P. Jacquemont, M. Davanture, G. Sandberg, M. Zivy, and C. Bellini. 2006. Proteomic analysis of different mutant genotypes of Arabidopsis led to the identification of 11 proteins correlating with adventitious root development. Plant Physiol. 140:349-364.

Svenson, S.E. and F.T. Davies, Jr. 1995. Change in tissue mineral elemental concentration during root initiation and development of poinsettia cuttings. HortScience 30:617-619.

Tukey, H.B., Jr. and S. Marczynski. 1984. Foliar nutrition-Old ideas rediscovered. Acta Hort. 145:205-212.

Tukey, H.B., S.H. Wittwer, and M.J. Bukovac. 1961. Absorption of radionuceotides by aboveground plant parts and movement within the plant. J. Agr. Food Chem. 9:106-113.

Weinbaum, S.A. 1996. Foliar nutrition of fruit trees, p. 81-100. In: Neumann, P.M. (ed.). Plant growth and leaf applied chemicals. CRC Press, Boca Raton, FL.

Wilkerson, E.G. and R.S. Gates. 2005. Transpiration capacity in poinsettia cuttings at different rooting stages and the development of cutting coefficient for scheduling mist. J. Amer. Soc. Hort. Sci. 130:295-301.

Wojcik, P. 2004. Uptake of mineral nutrients from foliar fertilization. J. of Fruit and Ornamental Plant Research 12:201-218. 